\title{
頭頸部外傷後遺症患者の臨床的観察
}

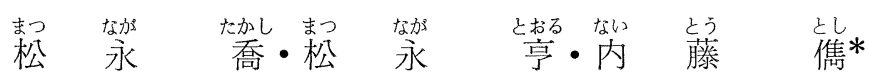

I は じめに

近代産業の発展に伴なう最近の都市を中心とした交通量の過密化，交通機関のスピード化，多様 化は必然的に交通事故の激増を来たし，その結果頭頸部外傷患者は日毎に増加しているそその初発 症状あるいは後遺症として各種の “めまい”を訴えるものが多く，ために平衡機能検查に異常を示 すものが多い事もしばしば報告されている。しかしかかる外傷時解剖学的傷害部位が充分明確でな い事も多く，また後遺症にしても，その pathogenesis が充分説明できない場合が多い，

今回はかかる頭頸部外傷患者の後遺症としての臨床像を耳鼻科的に検討し，聴力検査，平衡機能 検査わよび二，三の臨床検査を行ない，乙れらょり傷害部位の病巣鑑別の足掛りをつかむべく検討 したので報告する。

\section{II 観察対象および観察方法}

我々が今回取扱った頭頸部外傷患者は，第 1 表のごとく，昭和42年10月より昭和43年 9 月ま での一年間に，大阪大学耳鼻咽喉科外来を受彰 したもののうち，観察の対象になり得た男子76 名，女子 22 名，計 98 名である。 その性別，年令 は第 1 図のごとくで，最低18才より最高68才ま での各年代層にわかれている.

今便宜上，患者の受傷時の状沅をできるだ け，正確に聞きただし，その受傷時様式によ り, 頭部に直達力の加わった頭部外傷群を $\mathrm{A}$ 群，頭部外傷なく，体軀幹に加わった衝撃力 (加速あるいは減速)により頸部におこる急激な 過伸展, 過屈曲の結果として生じたいわゆる鞭 打ち損傷群を $\mathrm{G}$ 群，および両者の合併した群を B 群とし，98名の患者を第 2 表のでとく A（38 名)， B (34名)， $\mathrm{C}$ (26名)の三群に分けた。

第 1 表 頭頸部外傷患者数 （昭和42年10月～43年 9 月）

\begin{tabular}{cc}
\hline $\begin{array}{c}\text { 合 } \\
+\end{array}$ & $\begin{array}{l}\text { 76例 } \\
22 \text { 例 }\end{array}$ \\
\hline 計 & 98 例
\end{tabular}

ついで，てのA，B，Cの三群について以下 の検査を行った。すなわち

（i）受傷直後および後遺症としての臨床症 状の正確な聴取をすること.

(ii) 純音閾值聴力検查

性别书よで年令别

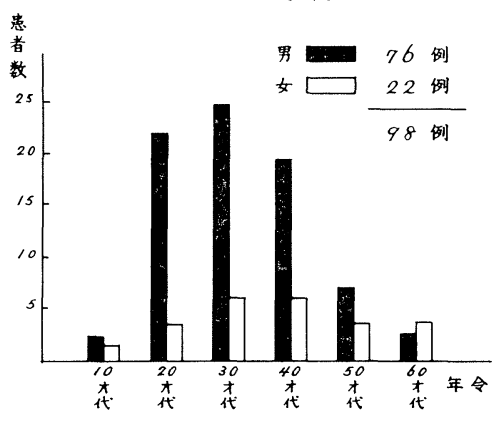

第 1 図

第 2 表 受 傷 様 式

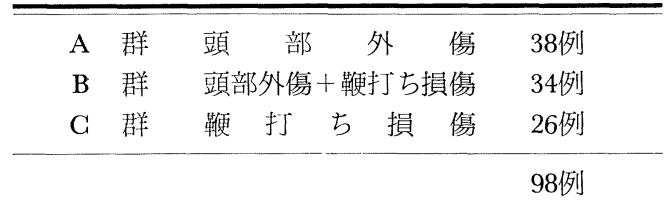

Glincal Observations on Whiplash Injuries of the Head and Neck

Takashi Matsunaga, Tōru Matsunaga and Toshi Naitō

* 大阪大学医学部耳鼻咽喉科学教室 (主任 : 内藤 㑺教授) 
(iii) 前庭平衡機能検査

(a) ルーチン平衡機能検査

(b) 振子様回転検査 ${ }^{1) 7}$

末梢迷路性眩軍および中枢性眩军の鑑別骖断 に，我々が以前より用いている振子様回転検査 (centric and eccentric pendular rotation test）を行った．本法は総脤门 $90^{\circ}$ ，周期 5 秒 で，左右に振子様 回転する 電動式椅子（第 2 図）で，被検者を回転中心側椅子に坐らせた時 (centric 回転時) には, 角加速度が，中心より 1 米はなれた椅子に坐らせた時 (eccentric 回 転時）には，角加速度のほかに直線加速度が作 用するようにしたものである。との検査法で centric 回転時と eccentric 回転時に，それぞ れ ENG そより回転中眼振を記録し，その眼 振数の左右差の変動（増加あるいは減少など） を検討した。

(c) 視標追跡検査 (eye tracking test) (ETT) 視標追跡検査をメトロノームを利用して 3 分 間連続追跡させと行い，その際の眼球運動の追 従波形を ENG で記録して調べた。すなわち メトロノームの尖端に直径 $2 \mathrm{~cm}$ の円型の指標 をつけ，毎分 40，60，90，120 の四段階の速さ

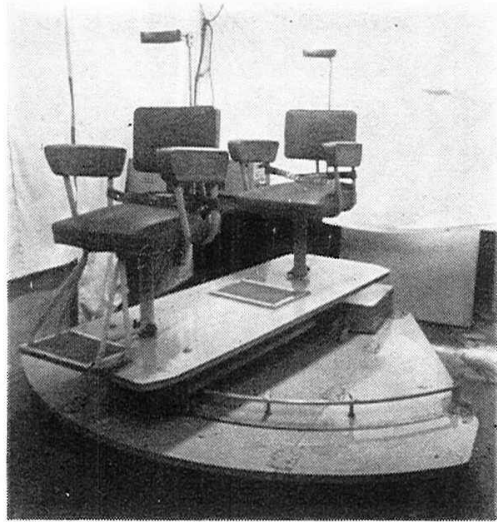

第 2 図 振子様回転椅子概観

で，從って每秒 $0.7 ， 1.0,1.5,2.0$ ヘルツの速 さで，それぞれ 3 分間動かし，被検者には，そ の指標を眼で追跡するように命じた。 その時の 眼球運動の波形，規則性， 3 分間連続刺激によ る追跡能への影響などを調べた。

(iv) Aschner test ${ }^{2)}$, Schellong test ${ }^{2)}$

(v) 矢田部 - Gilford, Cornell Medical Index (CMI) による性格調査 の諸検査を行ない，特にA群と $\mathrm{C}$ 群との間に何 らかの差異がみられないかを検討した。

\section{III 観 察 結 果}

\section{（i）一般的統計事項}

受賃動機により98名の患者をみると第 3 表の ごとく交通事故によるものが，78名約80\%とほ とんどを占め，その中でも追突事故によるもの が40名と半数以上占めている.上方から物体

第3表 受 偕 動 機

\begin{tabular}{|c|c|c|c|c|c|}
\hline \multirow[t]{5}{*}{ 1. 交 } & 通 & 事 & 故 & & 78例 (79\%) \\
\hline & 追 & & 笑 & 40 例 & \\
\hline & 衝 & & 突 & $17 \prime \prime$ & \\
\hline & はオ & $2 ら れ$ & しる & $17 "$ & \\
\hline & そ & $\infty$ & 他 & $4 \prime \prime$ & \\
\hline 2. 打 & 撲 & 事 & 故 & & 15例 \\
\hline 3. 頮 & 落 & 事 & 故 & & 4例 \\
\hline 4. 樭 & 発 & 事 & 故 & & 1例 \\
\hline
\end{tabular}

が落下して頭部にあたった打撲事故は15名 $15 \%$ であった。かかる㭧者の耳舅科受診までの期間 注第 4 表のごとく，受傷後 6 ケ月から 1 ケ年と 僄延したものが多かった。

(ii) 臨床症状

まず初発症状の意識障害の有無に関しては

第 4 表 受諩までの日数

\begin{tabular}{cr}
\hline 7 日未満 & 1 例 \\
1 ケ月" & 11 例 \\
2 ケ月" & 12 例 \\
6 ケ月" & 31 例 \\
1 年" & 24 例 \\
2 年" & 13 例 \\
2 年以上 & 6 例 \\
\hline
\end{tabular}


第 5 表のでとく98名中58名までが，何らかの意 識障害を有していた，意識障害のあった時間を 分単位，時間単位，日単位に分けるとA群では 意識障害が数時間，数日間と長いものが多く，

C群では当然の事ながら，意識障害のあったも のが少なく，またあっても数秒間の軽度のもの ばかりであった。

患者の訴える愁訴のうち，めまいに関して は，全経過を通して初発症状を，その他の臨 床症状については，受診時症状を中心に，全経 過の愁訴について集計した。我々耳鼻科へ受診 するのは，受傷後 6 ケ月万至 1 ケ年のものが多 く，したがって，乙れらの愁訴はいわゆる後遺 症としての臨床症状の範疇に属するものがと んどである。

第 3 図，第 6 表は臨床症状を一括したもので ある。めまいの訴えが，我々の統計では98名中 89名90\%と多い.

頭痛，頭重感は諸家の統計同様，85\%とめま いを除けば，一般に頭頸部外傷後遺症の横綱格

第 5 表 意識障害の有無(98例)

\begin{tabular}{|c|c|c|c|c|c|c|c|}
\hline \multirow{2}{*}{$\begin{array}{c}\text { 意識障害 } \\
\text { の有無 } \\
\ddots \\
\text { 受傷様式 }\end{array}$} & \multicolumn{5}{|c|}{ 意識 障 害（+） } & \multirow{2}{*}{$\begin{array}{l}\text { 意識障 } \\
\text { 害 }(\text { (一) }\end{array}$} & \multirow{2}{*}{$\begin{array}{l}\text { 合 } \\
\text { 計 }\end{array}$} \\
\hline & $\begin{array}{l}\text { 数 } \\
\text { 分間 }\end{array}$ & $\begin{array}{l}\text { 数 } \\
\text { 時 } \\
\text { 間 }\end{array}$ & $\begin{array}{l}\text { 数 } \\
\text { 日 } \\
\text { 間 }\end{array}$ & $\begin{array}{l}1 \text { 間 } \\
5 \\
\text { 月 }\end{array}$ & $\begin{array}{l}\text { 不 } \\
\text { 明 }\end{array}$ & & \\
\hline 群 & 10 & 6 & 9 & 1 & 3 & 9 & 38 \\
\hline 群 & 16 & 4 & 1 & 0 & 1 & 12 & 34 \\
\hline 群 & 7 & 0 & 0 & 0 & 0 & 19 & 26 \\
\hline 小 & 33 & 10 & 10 & 1 & 4 & \multirow{2}{*}{40} & \multirow{2}{*}{30} \\
\hline 総計 & \multicolumn{5}{|c|}{58} & & \\
\hline
\end{tabular}

传连症x

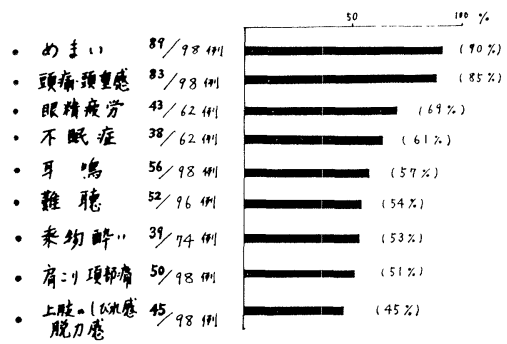

第 3 図
である。

新聞やテレビをみていると，すぐ眼が痚れ る，涙が出る，眼がかすむなど，いわゆる眼精 疲俘は69\%，受傷後の不眠症も61\%と案外多か った。

耳鳴，難聴などの蝸牛症状も57\%，54\%と過 半数以上に認められ，後遺症の中でも大きなウ エイトを占めていた。

受傷後乗物酔いを訴える患者も多かった。肩 こり，項部痛，上肢のしびれ感，脱力感など， いわゆる cervical syndrome としての一連の 症状のほか，亜心，咽頭不快感，舌のもつれ， 耳痛，耳閉塞感，脊腰痛，原因不明の微熱， 嗅覚障害などの症状，さらには性格の変調，記 銘才減退，性欲減退など多岐多彩な症状を訴え た

いまこれらの臨床症状と前述のごとき $\mathrm{A}, \mathrm{B}$ ， $\mathrm{C} の$ 三群，特に頭部外傷 $\mathrm{A}$ 群といわゆる鞭打ち 損傷 $\mathrm{C}$ 群との間に，何らかの差異かないかその 関連性を調べてみた。

まずめまいについては，第 7，8表に示すご とく各群共に大体同じ程度にめまいの発現をみ

第 6 表 後遺症としての臨床症状

\begin{tabular}{|c|c|}
\hline 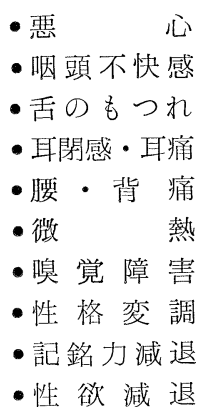 & $\begin{array}{l}23 / 40 \text { 例 } \\
13 / 40 \text { 例 } \\
11 / 40 \text { 例 } \\
9 / 40 \text { 例 } \\
4 / 40 \text { 例 } \\
4 / 40 \text { 例 } \\
5 / 51 \text { 例 }\end{array}$ \\
\hline
\end{tabular}

第 7 表 めまい 89/98例 $(90 \%)$

\begin{tabular}{|c|c|c|c|c|}
\hline & & 例 数 & $(+)$ & $(-)$ \\
\hline $\mathrm{A}$ & 群 & 38 & 37 & 1 \\
\hline B & 群 & 34 & 31 & 3 \\
\hline \multirow[t]{2}{*}{$\mathrm{C}$} & 群 & 26 & 21 & 5 \\
\hline & & 98 & 89 & 9 \\
\hline
\end{tabular}


第 8 表 受傷様式とめまいの種類

\begin{tabular}{c|r|r|r|r}
\hline めま受傷様式 & A 群 & B 群 & G 群 & 計 \\
の種類 & & & & \\
回 転 感 & 13 & 7 & 4 & 24 \\
動 摇 感 & 19 & 18 & 6 & 43 \\
眼前暗黒感 & 2 & 5 & 9 & 16 \\
平衡 障 害 & 3 & 1 & 2 & 6 \\
\hline 詀 & 37 & 31 & 21 & 89
\end{tabular}

第 9 表 めまい発症までの期間

\begin{tabular}{ccc}
\hline \hline 受 傷 直 後 & 17 例 \\
1 週 未 満 & 19 \\
2 週 & 11 \\
1 ケ月 & 11 \\
2 ケ月 & 10 \\
6 ケ月 & 9 \\
1 年 & 11 \\
不 & & 1 \\
\hline
\end{tabular}

第10表 頭痛・頭重感 83/98例(85\%)

\begin{tabular}{cc|c|c|c}
\hline & & 例 数 & $(+)$ & $(-)$ \\
\hline $\mathrm{A}$ & 群 & 38 & 30 & 8 \\
$\mathrm{~B}$ & 群 & 34 & 30 & 4 \\
$\mathrm{C}$ & 群 & 26 & 23 & 3 \\
\hline & & 98 & 83 & 15
\end{tabular}

るが，そのめまいの種類について患者に詳しく 聞いてみると，A群では回転感，動摇感など実 際に運動感のあるめまいが多かったのにくらべ C 群ではむしろ眼前暗黒感で代表される不定の めまいが多かった．前述のごとくめまいの愁訴 は，初発症状で集計したが，その発現は第 9 表 のごとく受傷後 1 週前後が一番多かった.

頭痛，頭重感などは本症に多い症状であるが 第10表のごとく A，C両群の間にほとんど差は なく出現していた。

難聴は第11表のごとく $\mathrm{A}$ 群が 38 名中 31 名 81 $\% ， \mathrm{C}$ 群が25名中 5 名 $20 \%$ と圧倒的に A群に多 いが，耳鳴はA群が38名中24名62\%，C群が26 名中 11 名 $42 \%$ と難聴の訴えの少ないC群でも，
比較的多かった。

上肢のしびれ感, 脱力感, 肩てり, 項部痛, 悪心などは，第12表のごとくG群に多くみられ た。

\begin{tabular}{|c|c|c|c|c|}
\hline \multirow[t]{2}{*}{ - 難 } & 聴 & & 11 表 & \\
\hline & & 例 数 & $(+)$ & $(-)$ \\
\hline A & 群 & 38 & $31(81 \%)$ & 7 \\
\hline B & 群 & 33 & 16 & 17 \\
\hline G & 群 & 25 & $5(20 \%)$ & 20 \\
\hline & & 96 & 52 & 44 \\
\hline
\end{tabular}

\begin{tabular}{|c|c|c|c|c|}
\hline - 耳 & 鳴 & \multicolumn{3}{|c|}{$56 / 98$ 例 $(57 \%)$} \\
\hline & & 例 数 & $(+)$ & $(-)$ \\
\hline A & 群 & 38 & $24(62 \%)$ & 14 \\
\hline B & 群 & 34 & 21 & 13 \\
\hline G & 群 & 26 & $11(42 \%)$ & 15 \\
\hline & & 98 & 56 & 42 \\
\hline
\end{tabular}

第 12 表

・上肢のしびれ感・脱力感 $45 / 98$ 例 $(45 \%)$

\begin{tabular}{cc|c|c|c}
\hline \hline & & 例 & \multicolumn{1}{|c|}{$(+)$} & $(-)$ \\
\hline A & 群 & 38 & $8(21 \%)$ & 30 \\
B & 群 & 34 & 20 & 14 \\
C & 群 & 26 & $17(65 \%)$ & 9 \\
\hline & & 98 & 45 & 53
\end{tabular}

・肩てり・項部痛 $50 / 98$ 例 $(51 \%)$

\begin{tabular}{cc|c|c|c}
\hline \hline & & 例 数 & \multicolumn{1}{|c|}{$(+)$} & \multicolumn{1}{|c}{$(-)$} \\
\hline $\mathrm{A}$ & 群 & 38 & $11(28 \%)$ & 27 \\
$\mathrm{~B}$ & 群 & 34 & 24 & 10 \\
$\mathrm{C}$ & 群 & 26 & $15(58 \%)$ & 11 \\
\hline & & 98 & 50 & 48
\end{tabular}

\begin{tabular}{|c|c|c|c|c|}
\hline • 恵 & 心 & \multicolumn{2}{|c|}{ 28/40例 } & \multirow[b]{2}{*}{$(-)$} \\
\hline & & 例 数 & $(+)$ & \\
\hline A & 群 & 11 & $5(45 \%)$ & 6 \\
\hline B & 群 & 15 & 8 & 7 \\
\hline G & 群 & 14 & $10(71 \%)$ & 4 \\
\hline & & 40 & 23 & 17 \\
\hline
\end{tabular}


その他の症状すなわち乗物酥い, 眼精疲学, 不眠症，咽頭不快感などは $\mathrm{A} ， \mathrm{C}$ 群同じ位にみ られた (第13表).

(iii) 検査成績

(1) 聴力検査

患者の自覚症状としての難聴は96名中52名54 $\%$ (第 3 図)にみられ，時には耳閉塞感もそれに 含まれるが，第11表のごとく側頭部に直達力の 受ける機会の多いA群に81\%と多い。乙れを純 音閾值検査によるオーヂオグラムと受傷様式と の関係で整理すると，第14表のごとくなり，96 名中54名に聴力障害が認められ, 高音漸傾型,

\begin{tabular}{|c|c|c|c|c|}
\hline & & 例 数 & $(+)$ & $(-)$ \\
\hline A & 群 & 25 & 11 & 14 \\
\hline B & 群 & 29 & 20 & 9 \\
\hline \multirow[t]{2}{*}{ G } & 群 & 20 & 8 & 12 \\
\hline & & 74 & 39 & 35 \\
\hline
\end{tabular}

\begin{tabular}{cc|c|c|c} 
- 眼精疲労 & \multicolumn{3}{|c}{$43 / 62$ 例 $(69 \%)$} \\
\hline & & 例 数 & $(+)$ & $(-)$ \\
\hline $\mathrm{A}$ & 群 & 16 & 9 & 7 \\
$\mathrm{~B}$ & 群 & 27 & 21 & 6 \\
$\mathrm{C}$ & 群 & 19 & 13 & 6 \\
\hline & & 62 & 43 & 19
\end{tabular}

\begin{tabular}{cc|c|c|c} 
- 不 & 眠 症 & \multicolumn{3}{|c|}{$38 / 62$ 例 $(61 \%)$} \\
\hline & & 例 数 & $(+)$ & $(-)$ \\
\hline $\mathrm{A}$ & 群 & 16 & 8 & 8 \\
$\mathrm{~B}$ & 群 & 27 & 18 & 9 \\
$\mathrm{G}$ & 群 & 19 & 12 & 7 \\
\hline & & 62 & 38 & 24
\end{tabular}

\begin{tabular}{|c|c|c|c|c|}
\hline \multicolumn{2}{|c|}{ - 詮頭不快感 } & \multicolumn{3}{|c|}{$13 / 40$ 例 } \\
\hline & & 例 数 & $(+)$ & $(-)$ \\
\hline A & 群 & 11 & 3 & 8 \\
\hline B & 群 & 15 & 6 & 9 \\
\hline $\mathrm{C}$ & 群 & 14 & 4 & 10 \\
\hline & & 40 & 13 & 27 \\
\hline
\end{tabular}

水平型など感音性難聴のタイプが多く，ついで $\mathrm{c}^{5}$ Dip 型のタイプが多かった。 とくにA群に は水平型，高音漸傾型を示したものが32名中 23 名 $71 \%$ （水平型12名，高音漸傾型11名）と多く を占めていた。

(2) 平衡機能検査

(a) ルーチン平衡機能検査

頭頸部外傷患者の後遺症としてめまいを訴え る割合は，諸家の報告でも相当に多い。ルーチ ン平衡機能検査は平衡神経科学会の基準に準じ て行った。第15表に 異常発現率をまとめてあ げ，さらに第16，17，18表に個々の検査と $\mathrm{A}$, $\mathrm{G}$ 二群との間の関係をあげた。

まず，眼振検查では，自発眼振 $(12 \%)$ 亿比し $\tau$, 頭位眼振 $(30 \%)$, 頭位.変換眼振 $(34 \%)$ 亿異

第14表 受傷様式と聴力像の関係

\begin{tabular}{|c|c|c|c|c|c|}
\hline 聴力像 & 受傷様式 & \begin{tabular}{|l|} 
頭部 \\
偒
\end{tabular} & \begin{tabular}{|c|} 
頭部外傷 \\
+ \\
鞭打ち損傷
\end{tabular} & 鞭打ち損傷 & 計 \\
\hline 正 & 常 型 & 6 & 15 & 21 & 42 \\
\hline 水 & 平 型 & 12 & 4 & 0 & 16 \\
\hline 高 音 & 漸 傾 型 & 11 & 5 & 1 & 17 \\
\hline 山 & 型 & 3 & 2 & 0 & 5 \\
\hline $\mathrm{C}^{5}$ & Dip 型 & 4 & 6 & 2 & 12 \\
\hline 谷 & 型 & 1 & 0 & 1 & 2 \\
\hline 全 & 竟 型 & 1 & 0 & 0 & 1 \\
\hline \multirow{2}{*}{ 高 音 } & 急墜型 & 0 & 1 & 0 & 1 \\
\hline & & 38 & 33 & 25 & 96 \\
\hline
\end{tabular}

第15表 平衡機能検查異常発現率

1）眼 振 検 查 自 発 眼 振 頭 位 眼 振 10/97例 $(12 \%)$ 頭位変換眼振 29/97例 $(30 \%)$ $33 / 97$ 例 $(34 \%)$ 頭振後眼振

$22 / 97$ 例 $(23 \%)$

2) 偏 倚 検 查 指示検查 2/97例 ( $2 \%)$ 7/97例 (7\%) 19/94例 (20\%) 14/92例 $(15 \%)$ $3 / 92$ 例 $(3 \%)$ 10/93例 $(10 \%)$ $37 / 95$ 例 $(38 \%)$ $38 / 91$ 例 (41\%) 
第16表 平衡機能検査成績(その一)

1) 眼 振 検 查

a) 自 発 眼 振

\begin{tabular}{ll|l|c|c|c}
\hline & & $\begin{array}{l}\text { 自発眼振 } \\
(+)\end{array}$ & $\begin{array}{l}\text { 自発眼振 } \\
(-)\end{array}$ & $\begin{array}{c}\text { *自発眼振 } \\
( \pm)\end{array}$ & \\
\hline $\mathrm{A}$ & 群 & $5(13 \%)$ & 32 & 1 & 38 \\
$\mathrm{~B}$ & 群 & 3 & 25 & 5 & 33 \\
$\mathrm{C}$ & 群 & $2(7 \%)$ & 24 & 0 & 26 \\
\hline & & 10 & 81 & 6 & 97 \\
\hline
\end{tabular}

b ）頭 位 眼 振

\begin{tabular}{ll|l|c|c|c}
\hline & & $\begin{array}{l}\text { 頭位眼振 } \\
(+)\end{array}$ & $\begin{array}{c}\text { 頭位眼振 } \\
(-)\end{array}$ & $\begin{array}{c}\text { *頭位眼振 } \\
( \pm)\end{array}$ & \\
\hline $\mathrm{A}$ & 群 & $12(32 \%)$ & 14 & 12 & 38 \\
$\mathrm{~B}$ & 群 & 11 & 14 & 8 & 33 \\
$\mathrm{C}$ & 群 & $6(23 \%)$ & 10 & 10 & 26 \\
\hline & & 29 & 38 & 30 & 97
\end{tabular}

c ）頭位変換眼振

\begin{tabular}{|c|c|c|c|c|c|}
\hline & & $\begin{array}{l}\text { 頭位変換 } \\
\text { 眼振 }(+)\end{array}$ & $\begin{array}{l}\text { 頭位変換 } \\
\text { 眼振 }(\text { 一) }\end{array}$ & \begin{tabular}{|c} 
*頭位変換 \\
眼振
\end{tabular} & \\
\hline A & 群 & $17(45 \%)$ & 14 & 7 & 38 \\
\hline B & 群 & 10 & 14 & 9 & 33 \\
\hline \multirow[t]{2}{*}{$\mathrm{C}$} & 群 & $6(23 \%)$ & 15 & 5 & 26 \\
\hline & & 33 & 43 & 21 & 97 \\
\hline
\end{tabular}

d）水平頭振後眼振

\begin{tabular}{cc|c|c|c|c}
\hline & & $\begin{array}{l}\text { 頭振眼振 } \\
(+)\end{array}$ & $\begin{array}{c}\text { 頭振眼振 } \\
(-)\end{array}$ & $\begin{array}{c}\text { *頭振眼振 } \\
( \pm)\end{array}$ & \\
\hline $\mathrm{A}$ & 群 & $11(29 \%)$ & 19 & 8 & 38 \\
$\mathrm{~B}$ & 群 & 6 & 21 & 6 & 33 \\
$\mathrm{G}$ & 群 & $5(19 \%)$ & 18 & 3 & 26 \\
\hline & & 22 & 58 & 17 & 97
\end{tabular}

* 眼球運動が不安定なもの

常発現が多く，特にA群により多くの眼振発現 が認められた。

またはっきりした眼振ではなく，いわ听る nystagmoid eye movement とも称せられる 眼球注視固定の不安定な状態を示す異常眼球運 動も，頭頸部外傷患者に多く認められた。しか も, この nystagmoid eye movement $は$, 上 述の jerky nystagmus の発現率と同に様に, 正常頭位検査時より頭位眼振検査，頭位変換眼 振検査，水平頭振後眼振検査時に多く発現し， また C群の方に発現頻度が高かった。
第17表 平衡機能検査成績(その二)

2）偏 倚 検 查

a) 指 示検 査 97例中 2 例 異常

b ） A $\mathrm{T} \quad \mathrm{R} 97$ 例中 7 例 異常

c ）遮眼書字検査(福田法)

\begin{tabular}{|c|c|c|c|c|}
\hline & & 遮眼書字 $(+)$ & 遮眼書字 $(-)$ & \\
\hline A & 群 & $10(28 \%)$ & 26 & 36 \\
\hline B & 群 & 5 & 27 & 32 \\
\hline \multirow[t]{2}{*}{$\mathrm{G}$} & 群 & $4(12 \%)$ & 22 & 26 \\
\hline & & 19 & 75 & 94 \\
\hline
\end{tabular}

d）足 踏 検 查

\begin{tabular}{ll|l|l|ll|l}
\hline & & $\begin{array}{l}\text { 足踏検查 } \\
(+)\end{array}$ & $\begin{array}{c}\text { 足踏検查 } \\
(-)\end{array}$ & 不 & 能 & \\
\hline A & 群 & $8(21 \%)$ & 27 & 3 & 38 \\
B & 群 & 2 & 30 & 1 & 33 \\
C & 群 & $4(15 \%)$ & 21 & 1 & 26 \\
\hline & & 14 & 78 & 5 & 97
\end{tabular}

e) 歩行検 查

\begin{tabular}{|c|c|c|c|c|c|}
\hline & & $\begin{array}{l}\text { 歩行検査 } \\
(+))\end{array}$ & $\begin{array}{l}\text { 歩行検查 } \\
(\text { 一 }\end{array}$ & 不 能 & \\
\hline A & 群 & 0 & 35 & 3 & 38 \\
\hline B & 群 & 2 & 30 & 1 & 33 \\
\hline \multirow[t]{2}{*}{ C } & 群 & 1 & 24 & 1 & 26 \\
\hline & & 3 & 89 & 5 & 97 \\
\hline
\end{tabular}

偏倚検査，立ち直り検査では $\mathrm{G}$ 群に比し $\mathrm{A}$ 群 に異常発現が多くみられた。

回転後 眼振検査（我々は手まわし式で，30 秒 5 回転刺激法を用いた)，温度検査（我々は $30^{\circ} \mathrm{C} ， 44^{\circ} \mathrm{C} ， 20 \mathrm{cc} ， 10$ 秒間注水による冷温交互 刺激法を用いた）では，A，C群共著明な差は みられず，40\%近い異常がみられたが，全体と して DP 所見が多く，中枢性にも末梢性にも 障害部位が推定できる事がうかがえた。

(b) 振子様回転検查

Centric and eccentric pendular rotation test.

成績は，第19表のごとくである，検査し得た 85名中 centric 回転時に比べ, eccentric 回転 時，眼振数の左右差が同じもの38名 (45\%)，増 加したもの 20 名 $(23 \%)$ ，減少したもの12名（14 \%)および左有差が逆転すなわち DP 方向が逆 
第18表 平衡機能検査成續 (その三)

3 ）立ち直り反射

\begin{tabular}{ll|l|l|ll|l}
\hline & & 転倒傾向 & $\begin{array}{c}\text { 転倒傾向 } \\
(+)\end{array}$ & 不 & 能 & \\
\hline $\mathrm{A}$ & 群 & $3(8 \%)$ & 33 & 2 & 38 \\
$\mathrm{~B}$ & 群 & 5 & 28 & 0 & 33 \\
$\mathrm{C}$ & 群 & $2(7 \%)$ & 22 & 2 & 26 \\
\hline & & 10 & 83 & 4 & 97
\end{tabular}

4) 回転後眼振検查 ( 5 回転/30秒 法)

\begin{tabular}{|c|c|c|c|c|c|c|}
\hline & $\begin{array}{l}\text { 正常 } \\
\text { 範囲 }\end{array}$ & $\begin{array}{l}\mathrm{DP} \text { を示 } \\
\text { すもの }\end{array}$ & $\begin{array}{l}\text { 眼振時 } \\
\text { 間延严 }\end{array}$ & $\begin{array}{l}\text { 眼振時 } \\
\text { 間短棭 }\end{array}$ & 小 計 & 計 \\
\hline A 群 & 20 & 16 & 1 & 0 & $17(46 \%)$ & 37 \\
\hline B 群 & 22 & 8 & 1 & 1 & 10 & 32 \\
\hline G 群 & 16 & 9 & 0 & 1 & $10(38 \%)$ & 26 \\
\hline & 48 & 33 & 2 & 2 & 37 & 95 \\
\hline
\end{tabular}

5 ) 温度性眼振検査 $\left(30^{\circ} \mathrm{C}, 44^{\circ} \mathrm{C}\right.$ 冷温交互法)

\begin{tabular}{|c|c|c|c|c|c|c|c|}
\hline & $\mid$\begin{tabular}{|}
$\mid$ 正常 \\
範囲
\end{tabular} & 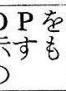 & 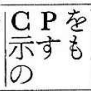 & $\begin{array}{l}\mathrm{DP}+\mathrm{CP} \\
\text { を示すも } \\
0\end{array}$ & $\mid \begin{array}{l}\text { 眼振 } \\
\text { 時間 } \\
\text { 趠長 }\end{array}$ & 小 計 & 計 \\
\hline A群 & 19 & 10 & 4 & 1 & 1 & $16(46 \%)$ & 35 \\
\hline B群 & 20 & 4 & 5 & 1 & 1 & 11 & 31 \\
\hline \multirow[t]{2}{*}{ G 群 } & 14 & 4 & 2 & 4 & 0 & $10(41 \%)$ & 24 \\
\hline & 53 & 18 & 11 & 6 & 2 & 37 & 90 \\
\hline
\end{tabular}

転したものや記録が不明瞭なものが15名となっ ている、 A， C両群の間に著明な有意の差はみ られない。

(c) 視標追跡検査 (ETT)

30名に行った ETT の成績は第20表のどとく である．30名中15名 $(50 \%)$ に異常な眼球運動 波形がみられた。

最初から全く規則性のない不規則な眼球運動 波形を示すものが30名中 9 名と最も多くみられ
(1)

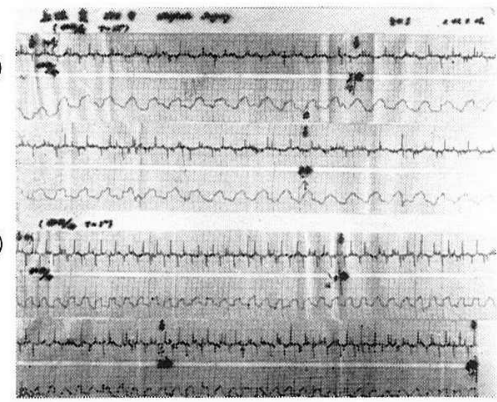

Whiplash injury の人の eye tracking test で眼 球運動が smooth でなく saccadic (階段状) であ る.（1）は 0.7 ヘルッ (2)は 1 ヘルッの周期で夫々 3 分間連続追跡させたものである.上段は微分波 形 (時定数 0.03 秒)，下段は原波形 (時定数 3 秒) である。

第 4 図 視 標 追 跡 検 査

た. Saccadic（階段状波形）を示すもの（第 4 図)，hypermetric(樹氷状波形）を示すものな どもみられた。かかるもので 3 分間指標を連続 追跡させると，最初眼球運動の波形が規則正し く出現していたものが，だんだんとその規則性: を失ない，時には眼球運動波形がー一時的に flat になる一我々は便宜上，易疲学性ありと言って いるーものが，15名中13名にみられ，特にC 群 に特徴的に多くみられた（第 5 図）

98名の症例中，眼精疲労を訴える患者につい ての ETT の成績は第21表のごとくで， C群 で注半数以上に正常の ETT 成續を示すもの がみられた。また同時に阪大病院眼科学教室に 依頼した眼球調節能力測定検查でも G 群では半 数以上に正常所見を示するのがみられた。そこ で ETT と眼球調節能力測定検查とを 同時に

第19表 Centric and eccentric pendular rotation test $の$ 成續

\begin{tabular}{|c|c|c|c|c|c|}
\hline 受伤様式 & cent. $=$ eccent. & cent. $<$ eccent. & cent.>eccent. & その他 & 計 \\
\hline 頭 部 外伤 & 16 & 5 & 5 & 8 & 34 \\
\hline 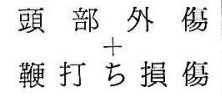 & 14 & 9 & 2 & 5 & 30 \\
\hline 鞭打ち損伤 & 8 & 6 & 5 & 2 & 21 \\
\hline 計 & 38 & 20 & 12 & 15 & 85 \\
\hline
\end{tabular}




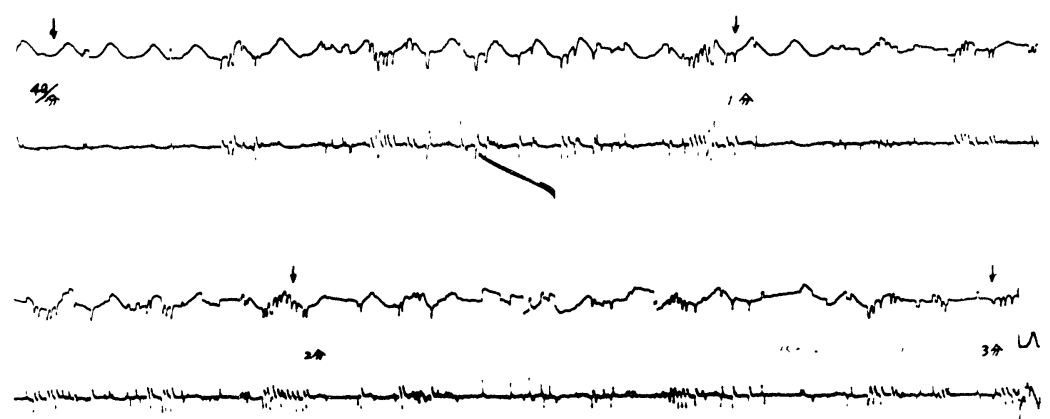

Whiplash injury の人の eye tracking test で眼球運動が極めて不規則で，長時間刺激で 易疲労性を示す。毎秒 0.7 ヘルツの周期で 3 分間連続追跡させたものである.上段は原波 形(時定数 3 秒)，下段は微分波形(時定数 0.03 秒)である.

第 5 図 視 標 追 跡 検 查

第20表 視標追跡検査所見

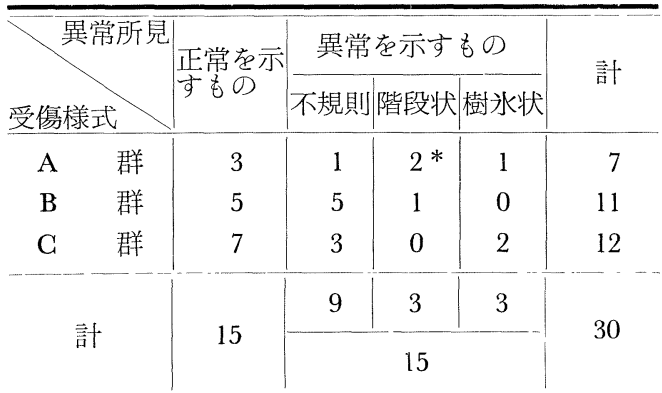

* 2 例は 3 分間の連続刺激で易疲学性を示さないも の，異常群15例のうち残りの13例はいずれも易疲 労性を示した

第 21 表

・視標追跡検查(眼振疲労を訴えるもの：30例)

\begin{tabular}{|c|c|c|c|c|}
\hline 受傷 & 㒸 式 & 例 数 & 異 & 正 \\
\hline A & 群 & 7 & 4 & 3 \\
\hline B & 群 & 11 & 6 & 5 \\
\hline $\mathrm{C}$ & 群 & 12 & 5 & 7 \\
\hline & & 30 & 15 & 15 \\
\hline
\end{tabular}

・眼球調節障害(眼精疲労を訴えるもの：32例)

\begin{tabular}{|c|c|c|c|}
\hline 受傷様式 & 例 数 & $(+)$ & $(-)$ \\
\hline 群 & 2 & 1 & 1 \\
\hline 群 & 16 & 10 & 6 \\
\hline 群 & 14 & 6 & 8 \\
\hline 計 & 32 & 17 & 15 \\
\hline
\end{tabular}

行った22名について両者の関係をみると，第 22 表のごとく，眼球調節能に異常のあるものは， ETT でも異常が多くみられ, 眼球調節能が正 常のものは EETでも正常所見を示す傾向のあ る事が分った。

(3) Aschner test, Schellong test

22名に無撰択的に Aschner test, Schellong test を行ったのが，第23表である. Aschner test では陽性が多く， Schellong test でも

\section{第22表 視標追跡検䍒と眼球調節能との関係}

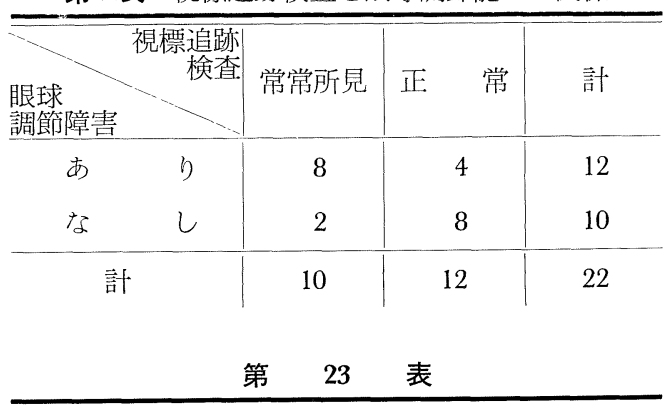

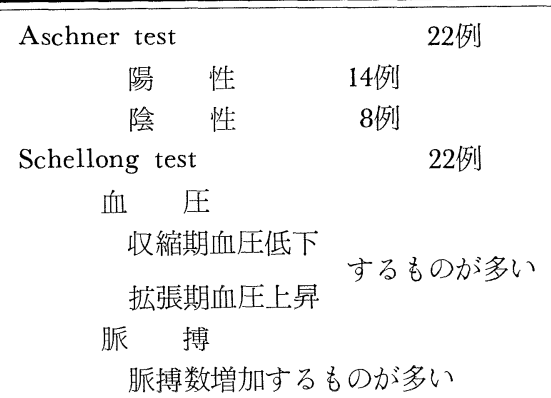


第24表 性 格 調 查

・矢田部・ギルフォード性格検査 61例 社会的適応・支配性大

衝動的・攻撃的・活動的

主導権をにぎる・情緒的安定 34例/61例

- Cornell Medical Index neurotic provisionally to be neurotic provisionally to be normal normal.

\begin{tabular}{l}
18 例 \\
15 例 \\
16 例 \\
15 例 \\
\hline 64 例
\end{tabular}

第25表 後遺症としての愁訴

\begin{tabular}{|c|c|c|}
\hline $\begin{array}{l}\text { 愁訴の発現率 } \\
\text { 愁 }\end{array}$ & $\begin{array}{c}\text { 頭部外傷群 } \\
\text { (A 群) }\end{array}$ & $\begin{array}{c}\text { 鞭打ち損傷群 } \\
\text { (C群) }\end{array}$ \\
\hline 頭 痛・頭重感 & $79 \%$ & $88 \%$ \\
\hline 耳鳴 & 62 & 42 \\
\hline 難 & 81 & 20 \\
\hline め ま い & 97 & 80 \\
\hline 上肢のしびれ・脱力感 & 21 & 65 \\
\hline 肩こり・項部痛 & 28 & 58 \\
\hline 悪 心 & 45 & 71 \\
\hline 乗 物 酔 い & 44 & 40 \\
\hline 眼 精 疲 労 & 56 & 68 \\
\hline 不眠 & 50 & 63 \\
\hline 咽頭 不快感 & 27 & 29 \\
\hline
\end{tabular}

註：頭部外傷群には交通事故以外に打撲墜落，爆 発事故なども含まれている。
第26表 平衡機能検査成績異常発現率

\begin{tabular}{|c|c|c|}
\hline 検查項目 & $\begin{array}{c}\text { 頭部外傷群 } \\
\text { (A群) }\end{array}$ & $\begin{array}{c}\text { 鞭打損傷群 } \\
\text { (C群) }\end{array}$ \\
\hline 自 発 眼 振 & $13 \%$ & $7 \%$ \\
\hline 頭 位 眼 振 & 32 & 23 \\
\hline 頭位変 換眼 振 & 45 & 23 \\
\hline 水平眼振後眼振 & 29 & 19 \\
\hline 指 示 检 査 & 5 & 0 \\
\hline 書 字 検 査 & 28 & 15 \\
\hline 足 踏 検 查 & 21 & 15 \\
\hline 歩 行 検 査 & 0 & 4 \\
\hline 立ち直り検査 & 8 & 7 \\
\hline 回転後眼振検査 & 46 & 38 \\
\hline 温 度 検 查 & 46 & 38 \\
\hline 振子様回転検查 & 38 & 57 \\
\hline 視 標追 跡 検查 & 57 & 41 \\
\hline
\end{tabular}

註：頭部外傷群には交通事故以外に打援墜落，爆 発事故なども含まれている，立ち直り検査は Romberg 検査のみの成績である。

陽性の傾问を示すものが多くみられた。

(4) 性格調査

矢田部・Gilford 性格検査, Cornell Medical Index を無撰択的に行った結果は，第24 表のごとくである。61名に行った矢田部・Gilford 検查では，社会的外向性を有し活動的で 主導権をにぎる性格を有し，情緒的にはむしろ 安定した性格の人が 61 名中 34 名にみられ，やや active な人間像がみられた。 CMI は64名に行 ったが，深町式判定により33名が neuroticな 性格を有し，特にC群に多かった。

\section{IV 総 括 と考 按}

池田 ${ }^{3)}$ の報告によると昭和41年度警察庁全国 統計では追突事故は約 5 万件で，乙れは交通事 故総数の約 $12 \%$ にたるという. 我々の98名の 症例中交通事故によるものが78名79\% と圧倒的 に多く，そのうち追突事故は40名で51\%の多き を占めている。乙れは大阪という交通過密都市 での症例であるためであろう。これに衝突事故 17名を加学ると，実に交通事故78名中，57名73 \%が車同志の事故で，日本の交通事故も欧米型
になり，自動車の定義も，走る凶器より走る棺 桶へと変えられるだろう。

かかる交通事故は，頭頸部外傷患者を生み， 特に追突事故が衝突事故より多い大都市では鞭 打ち損傷患者は急增している。さらにマスコう で報道されるようになった昭和40年以降が多く なって来ているという。その中には病気に対す る誤解，恐怖心，先入観より自分で鞭打ち症と 思い込んでいる患者が少なからずある。 
98名の症例は第 1 図のごとく，各年代層にわ かれているが，男子では20，30，40才代と受傷 機会遭遇の多い年:代に，当然の事ながら多発し ている.

白木，佐野 ${ }^{4)}$ によると，頭頸部外傷後遺症 として, 受傷後 3 週間を一応の基準にとり, こ の時点まで症状が続くものおよびての時点以後 で症状が発生するものをその範疇に入れてい る. 我々耳鼻科へ受診するのは, 受傷後 6 ケ月 前後（第 4 表）の遷延例が多く，いずれも頑固 な後遺症患者としての資格を持っているといえ る.との点がまた，耳鼻科医が頭頸部外傷患 者の生々しいデータをとら光難い由縁でもあろ う.

患者の訴光る愁訴は，一般的には頭痛，頭重 感, 頸部痛, めまいなどが多い。めまいの訴え が98名中 89 名 $90 \%$ と多いが，乙れは我々が今回 の報告で, 頭頸部外傷㭧者のうち，めまいを訴 える患者を重点的に診察, 検査したためであろ うと思う。これは檜 ${ }^{5}$ の統計でも同じでめまい を專攻している耳鼻科医の統計では, 頭頸部外 傷患者の愁訴のうち，めまいの占める割合が高 い. しかし他科の諸家の統計でも大体高率にみ とめられている。めまいの発現は, 第 9 表のご とく受傷後 1 週間前後が一番多かったが，乙れ は受傷時衝撃の程度およびそれに伴なう安静加 療の程度など色々な問題を含んでいる事を考慮 に入れねばならない。

頭痛, 頸部痛あるいはこの病気に対する不安 感，あせりあるいは賠償問題への苛ら立ちなど に起因する不眠症が $61 \%$ と多いが，乙の事が， ぬまい, 頭重感, 頭痛, 耳鳴などの色々な後遺 症を更に治り難くしているように思われる。

また受傷後乗物醉いを訴える患者が多い事実 は, 加速度受容器としての迷路と脳幹および自 律神経系との結び付きにおいて興味ある点であ る。

要するに局所症状以外飞多岐多彩な臨床症状 を訴える割には，他覚的所見の乏しいのが本症 の特徵であろう。
我々は98名の患者をその受傷様式により頭部 外傷群 (A群) 38名, 鞭打ち損傷群 (C 群) 26 名および頭部外傷十鞭打ち損傷群 (B 群) 34名 の三群に分けた。このように便宜上分汀る事に より，臨床症状あるいは検査成績上に何らかの 差異がみられないかを調べ，あわせて受傷機序 による障害部位を推定にようとしたのである。 特にA群とC群間に差異がないか調べてみたの である.

まず臨床症状はどうであろうか。めまいの発 生率は両群同じようにみられる。めまいの種類 ではA群は回転感, 動摇感など害際に運動感の あるものが多かったのに反し，C群では眼前暗 黒感など不定なものが多く，乙の点からはC 群 には末梢迷路障害は少ないと思われる。難聴は 第11表のでとく頭部に直達力を受ける機会の多 かったA群が 81\%と区倒的に多く訴えている が，耳鳴は難聴の訴光の少ないC群（20\%）で も $42 \%$ と可成り訴えている.

上肢のしびれ感，脱力感，頸部痛，肩こり， 悪心などは第12表のごとくC群に多く，性格の 変調（怒りやすくなった，いらいらする，短気 になったなど）や，記銘力の減退，物忘れなど はA群に多く，A群の耳鳴を訴える患者の方が C 群のそれより治りやすい傾向にあるなど受傷 機序の相異が関係していると考えられる点もあ った。しかし全体としては, 症状の発生機序の 複雑さを物語っているごとく一定の傾向は得ら れにくい，以上までの A， C兩群の後遺症とし ての臨床症状の集計は第25表のでとくである.

次に検査成績から A 群と C 群との相異をみる と, 聴力検查では第14表のごとく，A群で高音 漸傾型，水平型などのタイプが多く，ついで $c^{5}$ Dip 型も多い. C群でも $\mathrm{c}^{5}$ Dip 型は認めら れたが，他は例数が少なくて何ともいえない. この Dip 型聴力障害のあるものは, Békésyの 自記オーヂオメトリー, balance test などで 補充現象陽性が確かめられ, 内耳性難聴を肯定 しうる症例もあり, commotio labyrinthi と の関連において興味ある事実であった。しかし 
この際の平衡機能検査では，必ずしも未梢迷路 性障害を示さないのもあり，乙れは平衡迷路の 方は発生学的に primitiveな器官であり，し たがって聴覚迷路より刺激に対して抵抗性があ るのか，また頭頸部外傷という刺激が，聴覚迷 路には，全く異質の非適応刺激であるためか， あるいは平衡迷路の方は，その代償性により， 検査時には代償されてしまったため, 前述の如 く結果になったのかも知れない、いずれにして も, 乙の問題には, 我々耳鼻科医の今後の研究 課題が含まれていると思われる。

平衡機能検查については, 今回はルーチン検 查，振子様回転検查および ETT を行った。

ルーチン平衡機能検查では, 眼振検査で全症 例の $40 \%$ 近くに異常がみられ，特に頭位眼振， 頭位変換眼振にそれが多かった。 また眼球注視 固定の不安定なものは特にC群に誌められた。 立ち直り検査，偏倚検査では比較的異常が少な かった（10〜15\%）が，乙れは立ち直り検査と して Romberg 検査のみを取り上げたためで, Mann 検查では，さらに異常発現が多かった だろう。回転後眼振検查，温度検査では $40 \%$ 近 い異常がみられた。

一般に検查成績よりみると，A群には検查成 績相互間に納得のいく成績が多いが，C群では 各検查成績間に disharmony, discordance な ぞがみられ，説明し難い成績が少くない。乙れ は，頭部外傷には器質的損傷のあるものがある のに反し，C群では頸性眩暈, 頸耳性眩暈など の概念で説明しなければならない症例があるた めであろう。

検査成績の異常発現率を第26表にまとめたが 全体としては田村 ${ }^{6)} も$ 述べているように，A群 に異常発現が多くみられる傾向があっただけで 受傷様式の複雑さは, 頭部外傷, 鞭打ち損傷と clear cut 亿分け難い事を事を物語っている.

振子様回転検査での成績を説明する．85名の 患者に行った成績は第19表のでとくで，DP 方 向の逆転したもの, あるいは記録不明膫で判定 不能なもの計 15 名をのぞく70名中，病的所見の
認められたものは32名で約45\%にあたる。この 検査では, centric 回転時に比し, eccentric 回 転時に，回転中眼振数の左右差が増加するもの は，末梢迷路疾患であるとしているが，前記病 的症例32名の中に $20 \%$ 前後, centric 回転時に くらべ eccentric 回転時, 眼振数の左右差の増 加した症例があるが，乙れは末梢迷路障害を示 すと考えている。しかし，A，C両群の間に， 著明な有意の差はみられなかった。

我々の行った視標追跡検査はメトロノ一ムを 利用したもので，毎秒 $0.7 ， 1.0,1.5,2.0$ ヘルッ の速さで 3 分間連続視標を動かし，その際の眼 球運動の波形異常，3分間連続刺激中の波形 の規則性，易疲学性なぞを調べた。正常人で は, 各ヘルッ共 3 分間連続刺激をしても，指 標の動きと同じく，その眼球運動波形は，きれ いな正弦波形ないしは三角波形として記録され るが，頭頸部外傷患者では，不規則な波形を示 すもの，階段状波形を示すもの，樹氷状波形を 示すものなど， $50 \%$ 亿眼球運動波形の異常があ り，そのほとんどが長時間視標追跡していると 波形の規則性がなくなり，乱れが目立ち，同時 に検査中涙が出る，眼がいたい，ふらふらする， 頭がいたい，頭がボーとするなどの随伴症状を 訴えた。我々は，乙の眼球運動波形が検査中， 時間の経過と共に不規則に乱れて行くのを易疲 学性があるとしたが，特にC群にこの傾向が目 立った。乙れはまた98名中70\%近くに眼精疲学 を訴えたものがあり，特にG群にそれが多かっ た事よりうなづける事であった。

そとでかかる患者に対する simulationの鑑 別の必要上からも，ETTと阪大式アコモドメ 一ターによる眼球調節能力との相関性を調べた のが，第21，22表である。乙れでは眼精疲学を 訴えた症例の半数が ETT で正常であり，また 調節能力も半数が正常所見を示していた事，さ らに今回の症例の中で眼精疲学を訴光たものの うち22名に両方の検査を同時に行ってみると， $\mathrm{ETT}$ 亿異常のあるものは眼球調節能力障害が あり, ETT が正常のものは, 眼球調節能力も 
やはり正常が多いという傾向がみられる事より $\mathrm{ETT}$ が眼精疲学の客観化の一助になりうると 考えている.

以上の事実から, 頭頸部外傷後遺症には, 器 質的機能的病変以外飞何かプラスアルファーの 因子があるのではないかと思われるのである. ここにもこの疾患の病態のいとぐちがかくされ ているように考えるが，それを見つけ出す事は 難しく, 脳神経外科医, 整形外科医, 精神々経 科医，眼科医らおよびその患者の事故関係者と
のチームワークを待たねばならないだろう。

そてで我々は昭和 43 年 9 月より, 眼科, 脳神 経外科，精神々経科，レントゲン科，整形外科 災害外科の各担当医と共同して阪大鞭打ち研究 班を結成し，現在いろいろ検討を行っている。 近く報告する予定 ${ }^{8)}$ である.

今後頭頸部外傷後遺症の病態, 耳鼻科医とし てめまい, 耳鳴, 難聴の発生機序, 障害部位, 治療などまだまだ究明すい゙き問題点もあるが, 今回は臨床データのみについて報告した。

\section{$\mathrm{V}$ ま と め}

頭頸部外傷後遺症患者 98 名の臨床症状, 聴力検査, 平衡機能検查成績より次の結論を得た。

（i）頭頸部外傷患者の後遺症としての臨床像は，各人各様，多種多様の病態を示し，頭痛，頭 重感，頸部痛，めまいを中心に自律神経不安定症状など多彩であるが，二，三の症状で受傷機序の 相異が関連しているものがみられた。

（ii）純音閾值聴力検查では，06名中 54 名56\%に病的聴力像がみられ，頭部外傷群は38名中32名 $84 \%$ ，鞭打ち損傷群は25名中 4 名16\%で圧倒的に前者に多くみられた.

(iii) 平衡機能検查では，全体として約40\%の異常発現をみたが，頭部外傷群の方が，頭位眼振 検査，頭位変換眼振検査，立ち直り検査，偏倚検査で約10～20\%多く異常を認めた。

（iv）また回転後眼振検查，温度検査，振子様回転検査，視標追跡検查では，約 $40 \% の$ 異常所見 が認められた。

（v）連続視標追跡検查では，臨床症状として多い眼精疲労の客観化の一助となりうる所見が得 られた。

（vi）受傷様式より分けた三群を臨床症状, 聴力検査, 平衡機能検査成績から見ると，他覚的所 見は頭部外傷群に多い。また未梢迷路障害も頭部外傷群に多く，鞭打ち損傷群では，非迷路性要素 によるものがみられた。

本論文の要旨は昭和 43 年 3 月 10 日第 142 回日耳鼻大阪地方会, 昭和 43 年 10 月 24 日第 23 回日本平衡神経科学会 (岥阜市)および昭和 43 年 11 月 18 日頭頝部外傷後遺症としてのメマイの文部省班研究 (ホテル阪神) にて発表した。

\section{参 考 文 献}

1）松永 亨, 富山要二, 松永 喬, 内藤 㩦: 振子 様回転検查法について，耳鼻 14 : Suppl. 1 ; 89〜103、1967 (昭43)

2）金井 泉：臨床検査法提要，金原出版，東京， 1963(昭38)

3）池田亀夫ほか：いわゆる鞭打ち損賃に関する臨床 的研究，日整会誌 $42: 7 ; 473 \sim 489,1968$ (昭 43 )

4）白木博次，佐野圭司，椿 忠雄：脳を守万う，岩 波新書，東京，1968(昭43)
5）桧 学：頸性めまい，脳，神経外傷 1：1; 81 62，1969 (炤44)

6）田村益己：頭頸部外傷後遺症としての胘暈, 耳鼻 臨床 $63: 3 ； 241 \sim 254 ， 1970$ (炤45)

7) 富山要二 : Centric \& Eccentric Pendular Rotation Test の臨床的ならびに実験的研究, 日耳鼻, $72: 7 ; 38 \sim 55,1969$ (炤 44)

8）杉本 㑆, 松永 喬, ほ办: 鞭打ち損傷, 永井書 店, 1972(昭47)

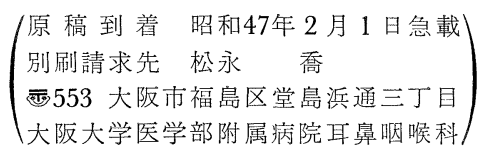

